\title{
The Impact of Human Capital Cost on Gross Domestic Product (GDP) in Nigeria
}

\author{
Sunday O. Effiok \\ Department of Accounting, Faculty of Management Sciences, University of Calabar \\ P.M.B. 1115, Calabar, Cross River State, Nigeria
}

Tel: 234-70-6705-2400

Arzizeh Tiesieh Tapang

Department of Accounting, Faculty of Management Sciences, University Of Calabar

P.M.B. 1115, Calabar, Cross River State, Nigeria

Tel: 234-80-3273-7920, 234-80-9551-4973Ｅ-mail: Arzizeh01@Yahoo.Com

Okon E. Eton

Department of Accounting, University of Port Harcourt, Port Harcourt, Rivers State, Nigeria

Received: June 25, 2012

doi:10.5430/ijfr.v3n4p116
Accepted: July 25, $2012 \quad$ Online Published: October 13, 2012

URL: http://dx.doi.org/10.5430/ijfr.v3n4p116

\begin{abstract}
This study aimed at determining the extent to which human capital cost influences gross domestic product in Nigeria. Hitherto, human resource was treated as expenses and written off in profit and loss account. No recognition was given to the skills of labour in human resource accounting and recently in intellectual capital. The research adopted a survey design for the study. The data collected were tabulated and analyzed using the Ordinary Least Square (OLS). The study revealed that human capital costs mirrored by acquisition, development, remuneration and protection costs do affect significantly gross domestic product in Nigeria. The study recommended that there is urgent need for the installation and maintenance of total quality management in Nigeria to enable it remains competitive in the global market. This is because employee's education, training and development are the key vehicle for building the economy and employee's capabilities. Finally, government should try to understand and appreciate the value of human capital as it is the most important determinant of it success.
\end{abstract}

Keywords: Human capital, Acquisition cost, Development cost, Remuneration cost, Protection cost

\section{Introduction}

The economic environment has shifted from industry based with focus on physical assets such as factory, machines and equipment to a high technology, information and innovation based environment with focus on expertise, talents, creativity, skills and experience of people - the company's human capital. This is because every business requires physical assets as well as human resources for its success. Without human resources and efforts physical assets like land, buildings, plants, machines and even the electronic gadgets become unproductive. All the activities, plans, strategies of a concern are initiated, executed, implemented, managed and controlled by the manpower that makes the concern. Profitability, productivity, solvency and efficiency of any organization are largely depended upon the human resources. Knowledge or skilled based companies are much richer than the physical or financial bearing companies. Since intellectual, experience, know-how, attitude, behaviour and value system of employees with a different way can improve the efficiency of production or services and create more wealth to an organization; human resources are the creative and innovative force which strives to secure maximum results (Brummet, 1970). The concept of human resource accounting is in the early stage of development in developing countries like Nigeria, Ghana, Cameroon, Congo DR etc. Similarly, the total worth of the organization depends mainly on the skills of its employees and the services they render. Hence, the success of this organization is contingent on the quality of their 
human resource. In knowledge driven economies therefore, it is imperative that the human elements be recognized as an integral part of the total worth of an organization. However, in order to estimate and project the worth of the human capital, it is necessary that some method of quantifying the worth of the knowledge, motivation, skills and contribution of the human elements be ascertained. Human Resource Accounting (HRA) denotes just this process of quantification/measurement of the human Resource (Prasad \& Kumar, 2006).

The concept of human resource accounting was first developed by Sir William Petty in the year 1691. "Research into true human resource accounting began in the 1960 by Rensis Likert". According to American Accounting Association (1974), human resource accounting is the process of identifying and measuring data about human resources and communicating this information to interested parties. Thus human resource accounting would measure all the data relating to people in an organization which will be helpful in making relevant decisions regarding internal and external matters. Like other physical assets human assets also have ability to create income. A person in appointed in a business concern and given services during bonded period, separation point or life normally up to supper annuation age. Therefore, it is necessary to value human force just as other assets (Cascio, 1998). A number of models have been developed to value human assets. A concern incurs two types of expenditure on human assets.

(i) Capital expenditure: which embodies acquisition, development, retention, updates or up gradation costs.

(ii) Revenue expenditure: including wages, salaries, bonus, commission, perquisites, allowances and short term motivation \& efficiency maintenance cost.

Value of human resource can be calculated either on the basis of cost of production approach or the capitalized earning approach. Capital expenditure are written off over the expected life of employees while revenue expenditure are written off or charged in company's profit \& loss account of current year (Cascio, 1998).

\subsection{Statement of the Problem}

Human resources have been identified as one of the main sources of competitive advantage by many organizations in today's economy (Edvinsson \& Malone, 1997; Sveiby, 1997; Mayo, 2001; DTI, 2003; Verma 7 Dewe, 2004). This is true not only of knowledge intensive organization, based on services and Intangible outputs, but also increasingly of more traditional organizations, both in the private and public sectors. However, human resources were still not recognized in the 1960s in techniques such as human resource accounting (HRA) and more recently, intellectual capital (IC) statements (Fincham \& Roslender, 2004; Roslender \& Dyson, 1992; Mourtisen, Cheek \& Fombrun, 2001).

\subsection{Objectives of the Study}

The main objective of this study is to determine the extent to which human capital cost influences gross domestic product. Therefore, the specific objectives of this study include:

1) To determine the extent to which acquisition cost affects gross domestic product.

2) To determine the extent to which development cost affects gross domestic product.

3) To determine the extent to which remuneration cost affects gross domestic product.

4) To determine the extent to which protection cost affects gross domestic product.

\subsection{Research Questions}

The research questions for the study are:

1) To what extent does acquisition cost affects gross domestic product?

2) To what extent does development cost affects gross domestic?

3) To what extent does remuneration cost affects gross domestic product?

4) To what extent does protection cost affects gross domestic product?

\subsection{Statement of Hypotheses}

The following null hypotheses are formulated and would be tested in order to authenticate the objectives of the study.

1) Ho: Acquisition cost does not significantly affect gross domestic product.

2) Ho: Development cost does not significantly affect gross domestic product.

3) Ho: Remuneration cost does not significantly affect gross domestic product.

4) Ho: Protection cost does not significantly affect gross domestic product. 


\section{Literature Review and Theoretical Framework}

\subsection{Theoretical Framework}

Theoretical perspectives based in sociology, economics, management, and psychology focus on different aspects of the domain of human capital (Wright \& McMahan, 1992). The study begins by offering brief summaries of the perspectives that have guided the empirical studies reviewed in this study and that we feel are most likely to drive future research.

\subsubsection{Human Capital Theory}

The value added that people can contribute to an organization is emphasized by human capital theory (Boxall, 1999). It regards people as assets and stresses that investment by organization in people will generate worthwhile returns. The theory therefore underpins the philosophies of human resource management and human asset management (Armstrong 2006).

Human capital theory is associated with the resource view of the firm as developed by Barney (1991). This proposes that a suitable competitive advantage is attained when the firm has a human resource pool that cannot be imitated or substituted by its rivals. Boxall (1999) refers to this situation as one that confers human capital, and human process advantage. But he also notes that a distinction should be made between 'human capital advantage and human process advantage'. The former results from employing people with competitively valuable knowledge and skills, the latter, however, follows from the establishment of "difficult to imitate, highly evolved processes within the firm such as cross departmental cooperation and executive development. Accordingly, human resource advantage, the superiority of one firm's labour management over another can be thought of as the product of its human capital and human process advantage.

For the employee, investments in training and developing people is a means of attaching and retaining human assets as well as getting better returns from those investments. These returns are expected to be improvements in performance, productivity, flexibility and capacity to innovate that should result from laying the skill base and increasing levels of knowledge and competence. Schuller (1997) suggests that; the general message is persuasive; skills knowledge and competencies are key factors in determining whether organizations and nations will prosper. This point is also made powerfully by Itami (1987).

But Daveport (1999) has some cautioning words about the asset based content of human capital theory. He argues that workers should not be treated as passive assets to be bought, sold and replaced at the whims of their owners.

Important though human capacity theory may be, interest in it should not direct attention from the valuation and reporting of human asset of the enterprise which include intellectual capital, social and organizational capital which are concerned with developing and embedding the knowledge possessed by human asset of the organization.

\subsubsection{Resource Based Theory of the Firm}

Recent theoretical work on the resource-based view of the firm supports the notion that human resource valuation may be an important source of competitive advantage. This theory was propounded by Barney. Barney (1991) argued that resources led to sustainable competitive advantage when they are valuable, rare, inimitable and non-sustainable. While technology, natural resources and economics of scale can create value, resource-based theory argues that these sources of value are increasingly available to almost any one anywhere and they are easy to copy, especially when compared to complex social systems like human resource systems (Ulrich \& Lake, 1990). As a result, several authors (e.g. Pfeffer, 1994; Snell, Mark \& Patrick, 1966; Wright \& Mc Mahan, 1992) have contended that human resource systems may be a better source of core competencies which can lead to sustainable competitive advantage. This interpretation is consistent with Arthur (1994), who suggests that core competencies are normally people embodied skills. As noted by Wright and Mcmahan (1992), since human performance is normally distributed, human resources meet the first two of Barney's criteria of being valuable and rare. Human resource management systems that successfully develop and engage employees to participate in companies activities are likely to enhance the value and rareness of company's human assets (Arthur, 1994). Further, unlike capital investment, or patents, a well developed human resource system is an invisible asset (Itami, 1987). Human resource strategies are difficult to imitate because of path dependency and casual ambiguity (Barney, 1991; Collins \& Montgomery, 1995). Human resource managements are path dependent since they consist of policies that have evolved over time. A competitor may understand that a particular human resource management strategy is valuable. However, because such systems are unlikely to work the same way if they were removed from the context where they are operating, a competitor cannot simply buy human resource management systems in the market. 
Wright and McMahan's work points to the importance of human resources in the creation of corporate specific competitive advantage. An issue then is whether or how firms can capitalize on this potential source of profitability. Barney (1991) contends that human resources are frequently underutilized because employees often perform below the maximum potentials and that the organizational efforts to elicit, discretionary effort from employees are likely to provide returns in excess of any relevant costs. Barney argues that human resource management practices can affect such discretionary effort through their influence over employee skills and motivation and through organizational structures that provide employees with the ability to control how their roles are performed.

Human resource valuation influence employee skills through the acquisition and development of a firm's human capital recruiting procedures that provide a large pool of qualified applicants, paired with a relief and valid valuation system will have a substantial influence over the quality and type of skills new employees possess.

\subsection{The Need for Human Capital Valuation}

The valuation of human resources is needed in all facets of the economy, be it service or manufacturing economy. The need to meet the increasing business opportunities of future, and simultaneously maintain or improve upon the current level of performance, has made organizations to look consciously into the manpower as the future leverage for success. The valuation of human resources helps in monitoring employees' performance. A human resource valuation report helps immensely in monitoring efficiency of personnel and designing the human resource strategy. The company can analyze it if its investment in human capital has paid off. Such a basis of Management Information System (MIS) reports on return on personnel cost and return on human capital. It also serves as a feeling of comfort for the company's employees that they are assets and not expenses of the firm.

Trends in the ration of investment in human assets to total assets may be a useful predictor of future profit performance. There is some evidence to indicate a degree of meaningful correlation between profitability of organizations and their expenditures on acquisition, training and retention of human resources (Ezewuchi, 2009).

The investors can also assess the return on human capital, which is in essence the return they are getting from those who are managing their wealth/investment. For the foreign institution investors, who are not fully aware of the day to day happenings of the company, human resource value reporting serves as a guide to their decisions. There are numerous studies (Elias, 1972; Ackland, 1976; Hendricks, 1976) indicating that human resource valuation information can affect investors' decision-making and their perceived value of a firm. All these were designed as decision-making experiments comparing balance sheets, including and excluding human assets. These experiments have been conducted with students (Elias, 1972; Hendricks, 1976) or bankers and financial analysts (Ackland, 1976). Furthermore, Elias (1972) and Hendricks (1976) examined the association between changes in decision and background factor. With one or two exceptions, they found no relationship, however. Based on a more recent study by Kerstein and Kim (1995), Hansson (1997) suggested that the Kerstein and Kim study shows that capital expenditures provide value-relevant and incremental information to investors. Their findings indicate that changes in capital expenditures are strongly and positively associated with excess return, i.e. one can earn a higher return by investing in firms that increase investments. However, when firms invest in their personnel, such investment is poorly signaled to investors because there is little or no information included in financial statement. The absence of human resource information could mean that the market would not be able to distinguish personnel investments from expenses. Whenever an investment is made (tangible or intangible), the firm is sacrificing cash flow today for a larger flow tomorrow. Because the value of a firm is normally based on evaluation of future cash flow, one can assume that the forecast would be much improved by knowing the amount invested. For firms with a larger proportion of their assets and investments in financially unaccountable human resources, the lack of information could lead to an underestimation of future earnings and return, if earnings reflect the firm's investment. Poor information or inferior information content in financial statement could also lead to uncertainty about the value of the firm. If one assumes that there is a shift towards intangibles (human resource) in generating future earnings, then there is possibly an increasing need for information about these investments (resources). Based on this reasoning, Hansson (1997) examined pricing in relation to knowledge-based firms and firms that are less dependent on human resources are followed by a rise in abnormal return. The results indicate that investors are not able to distinguish personnel investments from expenses, leading to an underestimation of earnings and return. Hansson asserts that investors may need accounting on human resources to help improve investment decisions.

Human resource valuation assures customers quality and consistency. It is a means of guarantee to customers and outsiders that the enterprises, through its personnel, are efficient to honor commitments. Depicting the value in the Balance Sheet and other reports can achieve a high level of motivation in the personnel and can communicate to them that the management perceives them as assets and not merely expenses. 
A human resource valuation reports help the management to make a conscious move to capture its cost related to human resource department by developing a human resource accounting system, which complements the human resource valuation exercise. The system can cause clarity in all relevant areas related to the human resource of the company. Human resource valuation is also useful in reporting on actions taken and results anchored in relation to objectives and goals. Information about the composition of investments in human resource can be analyzed to determine standard costs of recruiting, training and developing individual in order to bring them up to their present kevel of technical competence.

\subsection{Flamholtz's Model of Determinants of Individual Value}

According to Flamholtz (1999), the value of an individual is the present worth of the services that he is likely to render to the organization in future. As an individual moves from one position to another, at the same level, the profile of the services provided by him is likely to change. The present cumulative value of all the possible services that may be rendered by him during his/her association with the organization is the value of the individual.

Typically, this value is uncertain and has two dimensions. The first is the expected conditional value of the individual. This is the amount that the organization could potentially realize from the service of an individual during his or her service life in the organization. It is composed of three factors:

i. Productivity or performance (set or services that an individual is expected to provide in his or her present position)

ii. Transferability (set of service that he/she is expected to provide if and when he/she is in different positions at the same level)

iii. Promotability (set of services that are expected when the individual is in higher level positions).

These three factors depend to a great extent, on individual determinants like activation level of the individual (his motivation and energy level) and organizational determinants like opportunity to use the skill or roles and the reward system.

The second dimension of an individual values is the expected realization value, which is a function of the expected conditional value, and the probability that the individual will remain in the organization for the duration of his/her productive service life. Since individuals are not owned by the organization and are free to leave, ascertaining the probability of their turnover becomes important. The interaction between the individual and organizational determinants mentioned above, leads to job satisfaction. The higher the level of job satisfaction; the lower is the probability of employee turnover. Therefore higher is the expected realizable value.

\subsection{Flamholtz's Stochastic Rewards Valuation Model}

The movement or progress of people through organizational states or role is called a stochastic process. The stochastic rewards model is a direct way of measuring a person's expected conditional value and expected realization value. It is based on the assumption that an individual generates value as he occupies and move along organizational roles, and renders service to the organization. It presupposes that a person will move from one state in the organization to another during a specified period of time. In this model, exit is also considered to be a state. The use of this model necessitates the following information:

i. The mutually exclusive states that an individual may occupy in the system during his/her career.

ii. The value of each state, to the organization

iii. Estimates of a person's expected tenure in the organization

iv. The probability that in future, the person will occupy each state for the specified time.

v. The discount rate to be applied to the future cash flows.

A person is expected conditional value and expected realization value will be equal if the person is certain to remain in the organization, in the predetermined set of states throughout his expected service life.

The main drawback of this model, however, is the extent of information required to make the necessary estimates of the values of the service states, the expected tenure, and the probability that the individual will occupy the state for the specified period of time.

\subsection{Non Monetary Methods for Determining Human Value}

The monetary methods for assessing the economic value of human resources also measure human resource but not in monetary terms. Rather they rely on various indices or ratings and rankings. These methods may be used as 
surrogates of monetary methods to refer to a sample inventory of skills and capabilities of people within an organization or to the application of some behavioral measurement techniques to assess the benefits gained from the human resource of an organization. These methods are discussed below:

i. The skills or capability inventory: This is a simple listing of the education, knowledge, experience and skills of the firms' resources.

ii. Performance evaluation measures used in human resource valuation include ratings and rankings. Ratings reflect a person's performance in relation to a set of scales. These are scores assigned to characteristics possessed by the individual. These characteristics include skills, judgment, interpersonal skills; intelligence etc. ranking is an ordinal form of valuing in which the superior rank their subordinates on one more dimensions, mentioned above.

iii. Assessment of potential determines a person's capacity for promotion and development. It usually employs a trait approach in which the traits essential for a position is identified. The extent to which the person possesses these traits is then assessed.

iv. Attitude measurements are used to assess employees' attitudes towards their job, pay, working conditions etc; in order to determine their job satisfaction and dissatisfaction.

\subsection{Capitalization of Human Resource}

Bertolotti (1995) discusses three main methods to capitalize human resource;

i. Cost-based valuations which, however, fail to meet the recognition criterion of an asset because human resources may fail to contribute any value to the company.

ii. Economic valuations has two principal components, namely the identification, separation and qualification of the cash flows attributable to the human resources and capitalization of these cash flows. The advantage of this method is that it is based on cash flows not subject to the vagaries of different accounting treatments and focuses the thoughts of the valuer explicitly on (i) the future, as reflected by the financial projections, (ii) the risks associated with the asset and its associated cash flow stream, and (iii) the duration of the useful life of the human resources.

iii. By using market based methodologies, the value of the human capital is determined by reference to the price obtained for comparable assets in recent merger and acquisition transactions.

Researchers throughout the short history of human resources accounting have exploited all three approaches described above. Many models, developed mainly in the 1960s, were intended to value human resources derived from historical costs (Hekimian \& Jones, 1967), net present value of expected wage payments (Hermansson, 1964; Lev \& Schwartz, 1971; Friedman \& Lev, 1974), net present value of expected incomes Jaggi \& Lau, 1974; (Flamholtz, 1985), returns exceeding normal returns in comparable firms (Hermansson, 1964) and most recently, liabilities to the employees (Grojer, 1997). Whatever model is used financial ratios will be affected. This has been demonstrated by Groje who changed the content of the balance sheets in eleven Swidish firms by inserting figures on investments in training and recruitment and wage liabilities. As a consequence, liquidity, solvency and return on equity showed a reduction. The magnitude of the decrease was due to personnel intensity, wage structure and investments in recruitment and training.

Luecke and Garceau (2001) presents sizeable evidence on the decreasing usefulness of financial information to actors on the stock market. For example, about 90-95 percent of stock price changes for individual companies in the United States are unrelated to the firms' reported earnings. Based on findings from another study, Lev holds that what actually triggered stock prices were more timely released, such as product announcements etc. Some empirical evidence also exists indicating that managers are credible as forecasters. Forecasts of earnings have significant impact on stock prices and, in addition, they are superior to those made by analysts.

Financial reports present un-timing result of the lag between the occurrence of events and their consequences. In this respect, there is no difference between tangible and intangible assets. The majority of firms chose a pre-determined straight line or accelerated depreciation of historical cost values because of difficulties in predicting future benefits. To illustrate Lev compares real estate with software programs. Another shaky classification is the one on acquired assets (to be regarded as assets) and those internally generated to be exposed. Thus, he proposes a capitalization of expenditures to which future benefits could be attributed, e.g. Research and Development, product development, brand development, customer-based enhancement, restructuring and reorganization. Human capital is excluded because of difficulties in associating specific benefits with the costs. The outcome of this proposal would be a better 
matching of costs and benefits and hence a more meaningful portrayal of the firm's performance. It will additionally improve investors' possibilities to evaluate the success of the firm's innovative activities. To make them timely, historical-based reports have to be augmented with progressive financial reports that help illuminate expected consequences of managerial actions and external events.

Luecke and Garceau (2001) concludes that proposals to capitalize intangible assets have generally been opposed by managers, financial analyst, and accountants for the following reasons:

i. Intangibles are too uncertain to be considered as assets;

ii. Amortization of the capitalized values is subjective and could be misused to manipulate financial reports;

iii. The costs of intangibles bears no relationship to their real value in light of future benefits; and

iv. Failure of intangible projects presented in the balance sheets as assets may expose managers and auditors to frivolous shareholders' litigation.

However, based on the following arguments, Lev claims that these concern are overemphasized nothing that: (i) Investors already act as if organizations capitalize intangibles (2) while investors largely adjust for the expensing of intangibles, they also appear to sustainably discount the value of the intellectual capital; (3) research from recent acquisitions is in process. Research and Development and technology reveals a high correlation between prices paid for such intangibles and the cumulative cost of Research and Development of the required enterprises; and (iv) since 1985, most software producers have capitalized a portion of their Research and Development and product development costs in a manner similar to the proposed above without an emerged litigation avalanche. According to Lev, all of this makes a strong case for treating most intangibles the same as assets and for the systematic and universal measurement of intellectual capital.

\section{Methodology}

The research design adopted for the study was a survey design. This was because it sought to explain human capital cost and its impact on economic variable such as Gross Domestic Product (GDP). Data were obtained from secondary sources such as Central Bank of Nigeria (CBN), textbooks, gazettes, publications and internet.

\subsection{Model Specification}

The economic model used in the study (which is in line with what is mostly found in the literature) is given as:

$$
\mathrm{Y}=\beta_{0}+\beta_{1} \mathrm{~F}_{\mathbf{i t}}+\beta_{2} \mathrm{~F}_{\mathbf{i t}}+\mathrm{e}_{\mathbf{i t}}
$$

Where,

$$
\begin{array}{ll}
\mathrm{Y} & =\text { dependent variable } \\
\beta_{\mathbf{0}} & =\text { constant } \\
\beta & =\text { coefficient of the explanatory variable } \\
\mathrm{F}_{\text {it }} & =\text { explanatory variable } \\
\mathrm{e}_{\mathbf{i t}} & =\text { error term }
\end{array}
$$

By adopting the economic model as in equation (1) above specifically to this study, the model read as thus:

$$
\mathrm{GDP}=\mathrm{f}(\mathrm{AC}, \mathrm{DC}, \mathrm{RC}, \mathrm{PC})
$$

The statistical model becomes:

$$
\mathrm{GDP}=\beta_{0}+\beta_{1} \mathrm{AC}+\beta_{2} \mathrm{DC}+\beta_{3} \mathrm{RC}+\beta_{4} \mathrm{PC}+\mathrm{e}_{\mathrm{it}}
$$

Where;

$\begin{array}{ll}\text { GDP } & =\text { Gross Domestic Product } \\ \mathrm{AC} & =\text { Acquisition Cost } \\ \mathrm{DC} & =\text { Development Cost } \\ \mathrm{RC} & =\text { Remuneration Cost } \\ \mathrm{PC} & =\text { Protection Cost } \\ \beta_{0} & =\text { Unknown constant to be estimated } \\ \beta_{1} \& \beta_{2} & =\text { Unknown coefficients to be estimated } \\ \mathbf{e}_{\mathbf{i t}} & =\text { Stochastic error term } \\ \beta_{0}, \beta_{1}, \beta_{2} \beta_{3}, \beta_{4} & \geq 0\end{array}$




\section{Data Analysis}

$<$ Insert Table 1 here $>$

Table 1 shows the summary of the regression results of human capital cost (AC, DC, RC and PC) on Gross Domestic Product (GDP). From the result, it is found that all the independent variables are statistically significant in the model.

The explanatory power of the model as informed by the adjusted R-square is 0.923 or $92.3 \%$, and is statistically significant given the high value of the F-statistic (i.e. 18.82). The DW value is 2.088, which indicates that there exist no autocorrelation.

The model demonstrates a good fit given that about $92.3 \%$ of the variations in the dependent variable (GDP) are jointly explained by changes in the observed behaviour of AC, DC, RC and PC. The relatively high adjusted R-square value of $0.851(85.1 \%)$, shows that the model fits the data well. About $4.9 \%$ variations in GDP can be explained by other unknown variables not captured in the present model. The high significant F-statistic value $(4,10)$ of 18.82 confirms that the high adjusted R-square did not arise by chance [N/B: F0.01 $(4,10)=3.48]$. Therefore, the model is robust.

The test of significance shows that all the variables are significant when compared with the table value of 1.86 at $5 \%$ level, and then the four variables are statistically significant at 5\% level. Specifically, a $1 \%$ increase or decrease in, DC, RC and PC would lead to an increase or decrease in Gross Domestic Product (GDP) with a margin of 1.07, 0.47, 0.08 and 0.89 respectively.

The test for autocorrelation, the calculated DW is 2.137. From the table DW reading, one makes use of the following information: $\mathrm{K}=5$ variables, $\mathrm{n}=15$ and at $5 \%$ level: $\mathrm{du}=1.771,4-\mathrm{du}=2.229, \mathrm{dI}=1.335$ and $4-\mathrm{dI}=2.665$. By inspection, the DW value of 2.088 falls between du and 4du region (i.e. 1.771 and 2.229 in this case); it therefore implies that there exists no degree of autocorrelation.

\subsection{Discussion of Findings}

The findings of this study revealed that acquisition cost does affect gross domestic product. This result is in line with the findings arrived at by Delaney and Huselid (1996); Koch and McGrath (1996) who found out that investing in human capital acquisition is likely to have a positive impact on the extent to which the establishment actually succeeds in developing the skills/knowledge of its employees. The study also revealed that development cost is highly and significantly related to gross domestic product in Nigeria. This result is highly supported by MacDuffie (1995) who found out that positive relationship has been established between employee training and gross domestic product.

This study revealed that remuneration cost does significantly affect gross domestic product in Nigeria. This finding is consistent with the findings of Shou-yi (2004) who found out that if a State does not pay its workers as recommended by Employee Welfare and International Accounting Standard that State negatively motivates its employees and thus they are bound to perform below expectations. The finding of this study also shows that protection cost does affect gross domestic product. The finding of MFPRCC, (2006) is also in corroboration with the finding of this study. According to MFPRCC, (2006) most establishments failed today because they are unable to spelt out right defending cost in their annual report, there scaring most employees from performing their duties diligently as they feel not protected.

\section{Conclusion and Recommendations}

Just as the field of human resource accounting has grown globally, significant interest in HRA has expanded and crossed over in to fields others than accounting including economics, organizational management and organizational culture and inspired related research. This study has explored how human resource accounting measures incorporated corporate performance measurement system can help an organization define and orchestrate its strategy for success. The human resources cost approach to corporate performance measurement which has gained substantial attention and use in recent years provides further opportunities for utilization of human resource accounting measures. A growing number of studies have attempted to show the link between human resources and performance. We believe that though the case is not watertight, due to a number of methodological reasons, the weight of evidence is beginning to look compelling.

Having considered the findings from the data analyzed and conclusion of the study, the study therefore recommended that:

There is urgent need for the installation and maintenance of total quality management in Nigeria to enable it remains competitive in the global market. This is because employee's education, training and development are the key vehicle 
for building the economy and employee's capabilities. Finally, government should try to understand and appreciate the value of human capital as it is the most important determinant of it success.

\section{References}

American Accounting Association. (1974). Statement of basic accounting theory. The Accounting Review Supplement, 49, 85-93.

Bailey, T. (1993). Discretionary effort and the organization of work: Employee participation and work reform. NewYork: McGraw Hill.

Becker, B. E., \& Barry, G. (1996). The impact of human resources management on organizational performance: progress and prospects. Academy of Management Journal, 39(4), 779-801. http://dx.doi.org/10.2307/256712

Becker, B. E., \& Huselid, M. A. (1992). Direct estimates of SDy and the implications for utility analysis. Journal of Applied Psychology, 77, 227-233. http://dx.doi.org/10.1037/0021-9010.77.3.227

Becker, G. S. (1964). Human capital. New York: McGraw Hill

Boedker, C., Mouristan, J., \& Guthrie, J. (2008). Enhanced business reporting: International trends and possible policy directions. Journal of Human Resource Casting \& Accounting, 12(1), 14-15. http://dx.doi.org/10.1108/14013380810872734

Boudreau, J. W., \& Berger, C. J. (1985). Decision-theoretic utility analysis applied to employee separations and acquisitions. Journal of Applied Psychology, 70, 581-612. http://dx.doi.org/10.1037/0021-9010.70.3.581

Brummet, R. L. (1970). Accounting for human resource. The Journal of Accountancy, 4, 62-66.

Bullen, M. L. (2007). Human resource accounting: A useful tool for measurement and management in organizations. Leadership and Organizational Management Journal, 5, 85-103.

Cascio, W. F. (1991). Costing human resources: The financial impact of behaviour in organizations. Boston: PWS-Kent.

Cascio, W. F. (1998). The future world of work: Implications for human resources costing and accounting. Journal of Human Resource Casting \& Accounting, 3(2), 9-19. http://dx.doi.org/10.1108/eb029045

Davidove, E. A., \& Schroeder, P. A. (1992). Demonstrating return on investmen. [Online] Available: www.traininganddevelopment

Delaney, J. T., \& Huselid, M. A. (1996). The impact of human resource management on rerceptions of organizational performance. Academy of Management Journal, 39, 949-969. http://dx.doi.org/10.2307/256718

Flamholtz, E. G. (1979). Towards a psycho-technical systems paradigm of organizational measurement. Decision Sciences, 4, 71-84. http://dx.doi.org/10.1111/j.1540-5915.1979.tb00008.x

Flamholtz, E. G., Bullen, M. L., \& Hua, W. (2002). Human resource accounting: A historical perspective and future implications. Management Decision, 40(10), 947-54. http://dx.doi.org/10.1108/00251740210452818

Flamholtz, E. G., Bullen, M. L., \& Hua, W. (2003). Measuring the ROI of management development: An application of the stochastic rewards valuation model. Journal of Human Resource Costing and Accounting, 7(1-2), 21-40. http://dx.doi.org/10.1108/eb029077

Flamhotz, E. G., \& Lacey J. M. (1981). Personnel management, human capital theory, and human resource accounting. Los Angeles: Los Angeles University Press.

Frederickson, N. (1986). Toward a broader conception of human intelligence. American Psychology, 41, $445-452$. http://dx.doi.org/10.1037/0003-066X.41.4.445

Guest, D. E. (1997). Human resource management and performance: A review and research agenda. International Journal of Human Resource Management, 8, 263-276. http://dx.doi.org/10.1080/095851997341630

Hansen, B. (2007). Personnel investments and abnormal return. Journal of Human Resource Costing and Accounting, 2(2), 9-29. http://dx.doi.org/10.1108/eb029037

International Accounting Standards Board. (2009). Employee Benefits. [Online] Available: http://www.iasb.org Johanson, U., \& Mabon, H. (1998). The personnel economics institute after ten years. Journal of Human Resource Costing and Accounting, 19(2), 86-92.

Katz, D., \& Kahn, R. L. (1978). The social psychology of organizations. New York: Wiley. 
Koch, M. J., \& McGrath, R. G. (1996). Improving labour productivity: Human resource management policies do $\begin{array}{lllll}\text { matter. } & \text { Strategic } & \text { Management } & \text { Journal, } & \text { 335-354. }\end{array}$ http://dx.doi.org/10.1002/(SICI)1097-0266(199605)17:5<335::AID-SMJ814>3.0.CO;2-R

Kozlowski, S. W. J., \& Salas E. (1994). A multilevel organizational systems approach for the implementation and transfer of training. [Online] Available: www.trainingeffectiveness.org (August 4th, 2010)

Likert, R. M. (1960). The human organization: Its management and value. New York: McGraw-Hill.

Luecke, R. M., \& Garceau, E. G. (2001). Human organizational measurement: Key to financial success. MichiganBusiness Review, 4(1), 57-63.

MacDuffie, J. P. (1995). Human resource bundles and manufacturing performance: Flexible production systems in theworld auto industry. Industrial Relations \& Labour Review, 48, 197-221.

McKenzie, J. L., \& Melling, G. L. (2001). Skills-based human capital budgeting: A strategic initiative, not a financial exercise. Cost Management, 15(3), 30-38.

Meng-ya, Y. (2005). On human resources accounting practical application, China. Journal of Dalian Maritime University, 3(2), 32-40.

Moore, R. (2007). Measuring how human capital appreciates in value over time plant engineering. [Online] Available: www.humancapitalappreciates (June $24^{\text {th }}$ )

Porter, M. E. (1985). Competitive advantage: Creating and sustaining superior performance. New York: Free Press.

Prasad, M., \& Kumar V.S. (2006). Valuing human resource-an empirical approach: A case study of port of Visakhapatnam. Management and Accounting Research, 10(2), 6-17.

Russell, C. J., Colella, A., \& Bobko, P. (1993). Expanding the context of utility: The strategic impact of personnel selection. Personnel Psychology, 46, 781-801. http://dx.doi.org/10.1111/j.1744-6570.1993.tb01569.x

Schuler, R. S., \& Macmillan, I. C. (1984). Gaining competitive advantage through human resource management practices, Human Resource Management, 23(3), 241-256. http://dx.doi.org/10.1002/hrm.3930230304

Schwarz, J. L., \& Murphy, R. E. (2008). Human capital metrics: An approach to teaching using data and metrics to design and evaluate management practices. Journal of Management Education, 32(2), 164. http://dx.doi.org/10.1177/1052562907307638

Snell, S. A. (1992). Control theory in strategic human resource management: The mediating effect of administrative information. Academic Management Review, 35, 292-327. http://dx.doi.org/10.2307/256375

Subbarao, A. V., \& Zehgal, D. (1997). Human resources information and disclosure in annual reports: An international comparison. Journal of Human Resource Costing and Accounting, 2(2), 53-73. http://dx.doi.org/10.1108/eb029039

Toulson, P. K., \& Dewe, P. (2004). Human resource accounting as a measurement tool. Human Resource Management Journal, 14(2), 75-90. http://dx.doi.org/10.1111/j.1748-8583.2004.tb00120.x

Tsang, M. C, Rumberger, R. W., \& Levin, H. M. (1991). The impact of surplus schooling on worker productivity. Industrial Relations, 30, 209-28. http://dx.doi.org/10.1111/j.1468-232X.1991.tb00786.x

Von-Bertalanffy, L. (1950). The theory of open systems in Physics and Biology. Science 111, 23-29. http://dx.doi.org/10.1126/science.111.2872.23

Wan-xiang, L. (2001). On cost. Beijing: China Financial and Economic Publishing House.

Williamson, O. E. (1979). Transaction cost economics: The governance of contractual relations. Journal of Law Economics, 22(2), 233-261. http://dx.doi.org/10.1086/466942

Williamson, O. E. (1981). The modern corporation: Origins, evolution, attributes. Journal of Economics Literature, 19, 1537-1568.

Wright, G. Mckenzie, R. C., \& Muldrow, T. W. (1994). Human resources and the resource-based view of the firm. Journal of Management, 27, 701-721. http://dx.doi.org/10.1177/014920630102700607

Wright, P. M., \& McMahanm, G. C. (1992). Human resources and sustained competitive advantages: A resource-based perspective. International Journal of Human Resources Management, 5(2), 299-324.

Wright, P. M., \& Snell, S. A. (1991). Human resources management. [Online] Available: www.development/acq 
(June 23rd, 2010)

Yan-fen, L. (2002). Cost accounting. Shanghai: Shanghai University of Finance and Economics Press.

Table 1. Regression results of human capital cost and gross domestic product

\begin{tabular}{lllll}
\hline Variable & Coefficient & Std. Error & t-Statistic & Prob. \\
\hline C & 30137362.5 & 28425.26 & 2.060232 & 0.0002 \\
AC & 1.073883 & 8.654321 & 9.008101 & 0.0000 \\
DC & 0.472388 & 5.225201 & 4.812828 & 0.0006 \\
RC & 0.078459 & 0.432176 & 1.934987 & 0.0004 \\
PC & 0.890655 & 9.654329 & 7.342178 & 0.0000 \\
R-squared & 0.959105 & Mean dependent var & 111015.4 \\
Adjusted R-squared & 0.861353 & S.D. dependent var & 91204.24 \\
S.E. of regression & 67555.65 & Akaike info criterion & 25.21677 \\
Sum squared resid & $7.76 \mathrm{E}+10$ & Schwarz criterion & 25.36613 \\
Log likelihood & -249.1677 & F-statistic & 18.81531 \\
Durbin-Watson stat & 2.137312 & Prob(F-statistic) & 0.000000 \\
Method: Least Squares & & & \\
Sample(adjusted): $1997-2011$ & & & \\
Included observations: 15 after adjusting endpoints & & \\
Source: Researcher's estimation, 2012 & & \\
\hline
\end{tabular}

